\title{
Building Allies Coalitions: Why Formation Matters
}

\author{
Frances D. Butterfoss, PhD, MEd \\ Laurie L. Lachance, $\mathrm{PhD}, \mathrm{MPH}$ \\ Carlyn E. Orians, MA
}

This article describes how formation of the Allies Against Asthma coalitions was influenced by community context, history, leadership, membership, structure, processes, and other factors. Based on member surveys, key informant interviews, and self-assessment tools, results indicate that three coalitions developed from existing coalitions, and four formed in response to funding. The coalitions took an average of 12 months to form and completed $98 \%$ of formation tasks. Funding, technical support, and networking among grantees promoted formation. Although cultures, geographies, lead agencies, and years of experience differed, coalitions developed similar structures and processes. Two of three new coalitions took the longest to form, highlighting the need for flexibility and technical assistance when funding new coalitions.

Keywords: asthma; coalition; coalition formation; coalition development

$\mathrm{I}$ $\mathrm{n}$ the article by Butterfoss et al. (2006 [this issue]) the authors provided a description of how the Allies coalitions variably progressed through stages of development from formation to institutionalization. According to current theory, coalitions develop in stages and recycle through them as new members are recruited, plans are renewed, and/or new issues are added (Butterfoss \& Kegler, 2002; McLeroy, Kegler, Steckler, Burdine, \& Wisotzky, 1994). The first stage of coalition development is most often referred to as formation (Butterfoss, Goodman, \& Wandersman, 1993; Butterfoss \& Kegler, 2002), although others have

Health Promotion Practice

Supplement to April 2006 Vol. 7, No. 2, 23S-33S

DOI: $10.1177 / 1524839906287062$

○2006 Society for Public Health Education referred to it as planning (Fawcett, Paine, Francisco, \& Vliet, 1993) or mobilizing (Florin, Mitchell, \& Stevenson, 1993). For the purposes of this article, formation is the initial building of the coalition as an organization (Clark et al., 2006 [this issue]).

Formation usually begins when a lead agency with links to the community brings together key organizations that recruit a group of community partners to initiate a coalition focusing on a health or social issue of concern. Key leaders and staff are identified who develop structures (e.g., committees, rules) and operating procedures (processes) to promote coalition effectiveness. These structures help ensure that the coalition will assess the community, develop an action plan, and select and implement effective strategies. In this article, we describe how Allies coalitions were built and how the process itself may contribute to their effectiveness and longevity.

Editors' Note: This is one of two articles in this special edition that utilized the same methods to explore related aspects of coalition development. This article is part of a special supplement of Health Promotion Practice that describes the development and implementation of the Allies Against Asthma (Allies) initiative. Funded by the Robert Wood Johnson Foundation with direction and technical assistance provided by the University of Michigan School of Public Health, Allies provides support to seven community-based coalitions nationwide to develop, implement, and sustain comprehensive asthma management programs. Through Allies, each coalition received grants totaling approximately US\$1.5 million to support the coalition, its targeted activities, and evaluation for 1 year of planning and 3 to 4 years of implementation. The supplement describes the first phase of the initiative, during which coalitions designed and implemented a range of activities including improved access to and quality of medical services, education, family and community support, and environmental and policy initiatives. More information about the initiative and tools and materials developed by the coalitions can be found at www.AlliesAgainstAsthma.net. 


\section{The Authors}

Frances D. Butterfoss, PhD, MEd, is the director of the Consortium for Infant and Child Health (CINCH) and professor and head of Health Promotion and Disease Prevention at the Center for Pediatric Research at Eastern Virginia Medical School in Norfolk, Virginia.

Laurie L. Lachance, $\mathrm{PhD}, \mathrm{MPH}$, is the evaluation director of Allies Against Asthma, associate of the Center for Managing Chronic Disease, and an assistant research scientist in health behavior and health education at the University of Michigan in Ann Arbor, Michigan.

Carlyn E. Orians, MA, is an evaluation consultant for Allies Against Asthma and a senior research scientist at Battelle Centers for Public Health Research and Evaluation in Seattle, Washington.

\section{METHOD}

The Allies coalitions received minimal planning grants in 2001. Full implementation grants were awarded in 2002 to support 3 to 4 years of coalition efforts. During this latter period, various tools and methods were used to assess their formation and development.

The Coalition Self-Assessment Survey (CSAS; Kenny \& Sofaer, 2000) and Key Informant Interview methods are described more fully by Lachance et al. (2006 [this issue]). The CSAS surveys of members and staff were conducted annually from 2002 to 2004 and provide details about coalition leadership and membership, structure, function, and processes. CSAS results in this article represent the mean results from three surveys that were completed by a total of 280 of 400 eligible members from seven coalitions, for a response rate of $70 \%$. Results were analyzed within and across coalitions, although only summative data across all coalitions is presented here.

Key informant interviews were conducted with coalition members, community members, and staff from each of the seven coalitions ( $M=16$ interviews) to provide quantitative and qualitative information related to coalition structure and functioning, the focus of coalition efforts, and information about the social, cultural, and political environment of the community in which each of the coalitions operates (Lachance et al., 2006). Administered at baseline during the 1st year of implementation (2002) and again near the time of the final CSAS administration 2 years later (2004), all interviewers were tape-recorded, transcribed, and coded using content analysis of coalition structure, community readiness, and lessons learned by the coalitions.
The Coalition Effectiveness Inventory (CEI) and Timeline Exercise were completed by the project director and the project manager at each site at the end of Year 4 (2004). The CEI is a self-assessment tool that identifies whether coalition elements related to participants, processes, and structures are present (Butterfoss, 2004; Goldstein, 1997). The CEI is also used to rate the coalition's stage of development. This part of the CEI (22 items) was administered to project directors and managers to determine how well tasks were accomplished within stages of development: fully (score $=2$ ), minimally (score $=1$ ), or not at all (score $=0$ ). Coalitions could receive a maximum score of 42 . When a majority of 0 s is reported for any stage, then the coalition is rated as not achieving that stage. The number of items in each stage and sample items follow: Formation (4): permanent staff designated; Implementation (4): strategies implemented as planned; Maintenance (7): financial and material resources secured; and Institutionalization (6): activities incorporated within other agencies or institutions. The scores were averaged within and across stages for each site.

The Timeline Exercise was completed by one project director and one project manager in each site at the end of Year 4. The exercise asked respondents to retrospectively estimate the number of months that their coalition spent in each stage of development. The number of months was averaged for each stage and across all stages for the coalitions. Notably, some coalitions formed prior to Robert Wood Johnson Foundation (RWJF) funding while others were organized in response to this opportunity.

\section{RESULTS}

Allies coalitions took an average of 12 months to form. Fight Asthma Milwaukee Allies (FAM Allies) formed prior to funding; four coalitions (Consortium for Infant and Child Health [CINCH], King County Asthma Forum [KCAF], Philadelphia Allies Against Asthma [PAAA], and DC Asthma Coalition [DCAC]) finished formation within 6 months; Long Beach Alliance for Children with Asthma [LBACA] finished in 18 months, and Alianza Contra el Asma Pediátrica en Puerto Rico (the ALIANZA) in 30 months. Two of the three new coalitions took the longest to form. At the time of the survey, coalitions rated themselves (using the CEI) as having completed $98 \%$ of formation tasks. Data from CSAS and structured interviews provide a richer description of how coalitions were built and the factors that influenced the process. Factors that contributed to the formation of the coalitions are described in detail below: community context, history, 
lead agency, staff, leadership, membership, structure, processes, assessment, and planning.

\section{Community Context and History of Coalition Formation}

Coalitions are embedded in communities, and as a result, environmental factors can have a significant impact on coalitions (Butterfoss et al., 1993; Lasker, Weiss, \& Miller, 2000; McLeroy et al., 1994). Contextual factors are described as conditions that either exist or are lacking within an environment that can enhance or inhibit collaborations (National Network for Collaboration, 1996). Contextual factors include trust between groups, politics and administrative history of collaboration, geography and community readiness (Clark, Baker, \& Chawla, 1993; Dill, 1994; Gray, 1989; Kegler, Steckler, McLeroy, \& Malek, 1998; Nelson, 1994; Reininger, Dinh-Zarr, Sinicrope, \& Martin, 1999; Wolff, 2001).

Coalitions form for many reasons, as described by Clark et al. (2006) in an accompanying article. Three Allies coalitions developed from or were projects of previously existing coalitions. Of these, CINCH focused on other health issues for children in addition to asthma, while the other two preexisting coalitions, FAM Allies and KCAF, focused solely on asthma. Four developed as new coalitions in response to the RWJF funding opportunity: DCAC, LBACA, PAAA, and the ALIANZA. The ALIANZA partners had no history of previous collaboration. DCAC, FAM Allies, and KCAF shifted from other missions (media awareness and education) to comprehensive asthma management.

The ALIANZA was formed through the efforts of a Puerto Rican-born researcher from UCLA/RAND to develop a collaborative effort focusing on asthma in Puerto Rico. The RWJF Request for Proposals (RFP) provided the opportunity to develop a partnership between a researcher at the University of Puerto Rico, a hospital, and a local community-based organization to form the core of the ALIANZA. Prior to RWJF funding, organizations in San Juan had little experience with communitybased asthma intervention programs.

CINCH already had 7 years of experience as a coalition working on maternal and child health issues when it began to focus on asthma in response to a report that the coalition published in that year recounting the high number of hospitalizations because of childhood asthma. A new work group focused on asthma was formed, and RWJF funding was sought by the coalition leadership to build on work started by the group.

DCAC arose when several organizations-American Lung Association (ALA) of D.C., D.C. Department of Health, D.C. Hospital Association, and Howard University
College of Medicine-agreed to address D.C.'s childhood asthma epidemic. Despite the difficulty of merging organizational interests and the cultural and ethnic issues that make collaboration in D.C. challenging, stakeholders agreed to work together "for children in the District" and to apply for RWJF funding as a single entity, the DCAC coalition. As a result, DCAC shifted from initiating a public awareness campaign to creating sustainable systems change to address the fragmented pediatric asthma care in D.C. After addressing misgivings by some coalition members, DCAC built consensus for its new approach and expanded to more than 100 members representing 60 local and national organizations.

FAM Allies' predecessor, Fight Asthma Milwaukee (FAM), started 6 years prior to RWJF funding and was the most comprehensive asthma organization in Milwaukee. FAM focused on health care provider, parent, and school-based asthma education with little funding and a succession of fiscal agents. A group convened by FAM's lead agency, Children's Hospital and Health System, wrote the Allies proposal and merged with FAM to become FAM Allies. Like DCAC, transitioning from a patient-centered focus to a broader community mission was challenging. FAM Allies built on FAM's success and on the collaborative spirit that is reported to be part of "Midwest values and altruism."

KCAF convened 2 years prior to RWJF funding by the ALA of Washington and Public Health-Seattle and King County. KCAF had no funding or programs but was conceived as a network to promote sharing of asthma information. The RWJF application was the first time that KCAF applied for funding and was an opportunity to move beyond information exchange to asthma implementation. King County was home to many independent, uncoordinated asthma-focused activities (i.e., research, outreach, and education), and asthma experts knew each other well. An existing diabetes coalition served as a model for KCAF.

LBACA formed in response to the RWJF RFP. A core group began working on other community initiatives and recognized an opportunity to focus on asthma. The health department, a children's hospital, a physician, and a public health intern created the initial coalition framework. Describing themselves as "a coalition-rich, consortium kind of community," many of LBACA's partners had worked together on immunization, insurance, tobacco, and infant health. The community had limited experience collaborating on asthma.

PAAA formed in response to the RWJF RFP. Two nonprofit organizations took the lead: the Philadelphia Health Management Corporation (PHMC) and the Health Promotion Council (HPC). Philadelphia Health Management Corporation had infrastructure and evaluation 
research capabilities, including conducting a periodic household neighborhood health survey on access to care and service utilization (including asthma). Health Promotion Council was experienced in chronic disease prevention and management and built a tobacco control and prevention coalition. A more inclusive group of 40 partners met and agreed to respond to the RFP with HPC serving as the lead agency. Three other asthma partnerships existed before PAAA (ALA's Attack Asthma Coalition, Philadelphia Department of Health's Asthma Task Force, and the Mid-Atlantic Regional Asthma Initiative or MARAI) and all agreed to send representatives to PAAA.

\section{Lead Agency}

The lead agency or convener assumes the overall responsibility to mobilize community members to form a coalition focused on a specific issue of concern. In some cases, the lead agency has the vision to initiate the coalition and solicits more partners. In other cases, several partners respond to a need and identify one agency as the lead. Although many types of organizations can serve as lead agencies, certain characteristics build strong ones, such as (a) strong administrative and management infrastructure, (b) existing community relationships, and (c) understanding and support for coalition efforts, such as the capacity to provide leadership while allowing the coalition itself to define its efforts.

Allies' lead agencies include children's hospitals (CINCH, FAM Allies, and LBACA), a community foundation (DCAC), nonprofit organizations for research (the ALIANZA) and health promotion (PAAA), and a county health department (KCAF). Although all of these lead agencies provide grant management and leadership, their strengths and roles vary significantly. Five (CINCH, FAM Allies, the ALIANZA, PAAA, KCAF) provide physical space for coalition staff and activities, and six employ some coalition staff (most employ additional staff through contracts with partner organizations). Several bring additional specific strengths to the coalition. The lead agency in Philadelphia, for example, has a long-standing reputation as a neutral convener among the city's fiercely competitive health care institutions. Working through the agency enabled these institutions to put aside their individual interests and participate in the coalition as equal partners with a joint vision. In Milwaukee, where the local health system is the lead agency, the coalition benefits from access to affiliated clinical systems and engaged key stakeholders within the institution that led to ongoing financial support for the coalition and its work. Where the lead agency's capacities were not as strong, the coalition expected other partners to play that role, or struggled to compensate.

\section{Coalition Structures}

Coalitions are more likely to engage members, pool resources, and assess and plan well when they have formalized rules, roles, structures, and procedures (Butterfoss \& Kegler, 2002; Goodman \& Steckler, 1989; Kegler et al., 1998; Rogers et al., 1993). Formal structures may include steering committees, committees, and subcommittees; rules of operation, bylaws, or policy statements; written roles or job descriptions; mission statements, goals, and objectives; organizational charts; regularly scheduled meetings with agendas; and communication pathways. Allies coalitions reported they had or were developing each of these structures, except for one that lacked an organizational chart.

Each Allies coalition has a steering or executive committee made up of leaders from the work groups (committees), and five of them include at-large members who represent community organizations. The ALIANZA also has a community council that provides community input and oversees planning and implementation of community asthma awareness activities. CINCH and KCAF positioned their Allies groups as part of a larger umbrella coalition that provides direction, but not administrative management. Each coalition has four to six work groups $(M=4)$, and two coalitions have additional task forces or subcommittees. CINCH organizes its work groups around community and/or professional sectors, three coalitions (the ALIANZA, DCAC, FAM Allies) organize around tasks, and the remainder use a combination of sectors and tasks. Allies coalitions and committees meet at least quarterly, with some meeting more often. Table 1 describes the various committees, governing groups, and bylaw and/or rule structures.

According to informant interviews, committee structures varied across time. For example, KCAF started with four committees: Schools, Clinical Practice, Outreach and Education, and Community/Parents. Over time, two committees became inactive (Clinical Practice and Community/Parents) and the Outreach and Education Committee changed focus to become the Policy and Public Relations Committee. The Steering Committee started out by coordinating recruitment and referrals, "so that we weren't confusing people in the community and undermining each other's work." When strategies and projects were well established, its expanded role was to provide updates, disseminate programs, and make sure that members know "who is doing what in the 
TABLE 1

Organizational Structure, Leadership, and Governance of Allies Coalitions ${ }^{\mathrm{a}}$

\begin{tabular}{|c|c|c|c|c|}
\hline Coalition & $\begin{array}{c}\text { Steering and/or } \\
\text { Executive Committee }\end{array}$ & $\begin{array}{l}\text { Standing } \\
\text { Committees }\end{array}$ & $\begin{array}{c}\text { Other } \\
\text { Committees }\end{array}$ & $\begin{array}{c}\text { Formal } \\
\text { Documents }\end{array}$ \\
\hline $\begin{array}{l}\text { Alianza Contra el } \\
\text { Asma Pediátrica } \\
\text { en Puerto Rico } \\
\text { (ALIANZA) }\end{array}$ & $\begin{array}{l}\text { Community director, } \\
\text { representatives from } \\
\text { four founding and all } \\
\text { other organizations }\end{array}$ & $\begin{array}{l}\text { (3) Community council, } \\
\text { research and evaluation, } \\
\text { provider education and } \\
\text { clinical quality improvement }\end{array}$ & & None \\
\hline $\begin{array}{l}\text { Consortium for } \\
\text { Infant and Child } \\
\text { Health (CINCH) }\end{array}$ & $\begin{array}{l}\text { Chair and vice chair, } \\
\text { committee chairs and } \\
\text { vice chairs, } 3 \text { at-large } \\
\text { representatives }\end{array}$ & $\begin{array}{l}\text { (3) Health care providers, } \\
\text { community, schools }\end{array}$ & $\begin{array}{l}\text { Larger coalition w/ } \\
\text { five work groups, } \\
\text { activity task groups }\end{array}$ & Bylaws \\
\hline $\begin{array}{l}\text { DC Asthma } \\
\text { Coalition (DCAC) }\end{array}$ & $\begin{array}{l}15 \text { members elected } \\
\text { from slate of nominees }\end{array}$ & $\begin{array}{l}\text { (4) Environment, health } \\
\text { services, education, data } \\
\text { and surveillance }\end{array}$ & $\begin{array}{l}\text { Ad hoc activity task } \\
\text { groups }\end{array}$ & Informal rules \\
\hline $\begin{array}{l}\text { Fight Asthma } \\
\text { Milwaukee Allies } \\
\text { (FAM Allies) }\end{array}$ & $\begin{array}{l}\text { Chair and chairs of } \\
\text { committees }\end{array}$ & $\begin{array}{l}\text { (6) Family and community } \\
\text { education, clinical quality } \\
\text { assurance, care coordination } \\
\text { and case management, } \\
\text { evaluation and/or surveillance, } \\
\text { parent and/or neighborhood } \\
\text { organizing, communication }\end{array}$ & & Bylaws \\
\hline $\begin{array}{l}\text { King County } \\
\text { Asthma Forum } \\
\text { (KCAF) }\end{array}$ & $\begin{array}{l}\text { Chair and chair elect, } \\
\text { project directors, } \\
\text { primary investigators } \\
\text { of projects, committee } \\
\text { chairs, } 7 \text { at-large } \\
\text { representatives }\end{array}$ & $\begin{array}{l}\text { (4) Schools, clinical practice, } \\
\text { neighborhood, community } \\
\text { outreach }\end{array}$ & $\begin{array}{l}\text { Governance and cross- } \\
\text { project coordination } \\
\text { ad hoc committees }\end{array}$ & Bylaws \\
\hline $\begin{array}{l}\text { Long Beach } \\
\text { Alliance for } \\
\text { Children with } \\
\text { Asthma (LBACA) }\end{array}$ & $\begin{array}{l}\text { Chair, } 2 \text { members } \\
\text { from each committee, } \\
\text { at-large community } \\
\text { representative }\end{array}$ & $\begin{array}{l}\text { (4) Community and consumer, } \\
\text { policy and environment, } \\
\text { schools and recreation, } \\
\text { professional practices }\end{array}$ & $\begin{array}{l}\text { Communication task } \\
\text { force }\end{array}$ & $\begin{array}{l}\text { Guiding } \\
\text { principles, } \\
\text { protocol for } \\
\text { donations }\end{array}$ \\
\hline $\begin{array}{l}\text { Philadelphia Allies } \\
\text { Against Asthma } \\
\text { (PAAA) }\end{array}$ & $\begin{array}{l}3 \text { cochairs, } 24 \\
\text { members }\end{array}$ & $\begin{array}{l}\text { (6) Child Link Line, managed } \\
\text { care, community intervention, } \\
\text { communications and/or } \\
\text { public awareness, research, } \\
\text { sustainability }\end{array}$ & & $\begin{array}{l}\text { Standard } \\
\text { procedures, } \\
\text { rules for voting } \\
\text { and endorsing } \\
\text { members }\end{array}$ \\
\hline
\end{tabular}

a. Although these structures were in place during the majority of the Allies project, changes were made by the end of the funding period to make the coalitions responsive to community needs, for example, changes in number and scope of committees.

community." Similarly, PAAA agreed that coalition structure must be responsive to its function. A structure that "worked for big picture, visionary strategic planning wasn't necessarily the right structure for this [implementation] phase." Two original committees, Schools in Managed Care and Coordinated Access, were combined to form an Oversight Committee that coordinated access and integration of activities. When the coalition "identified the 


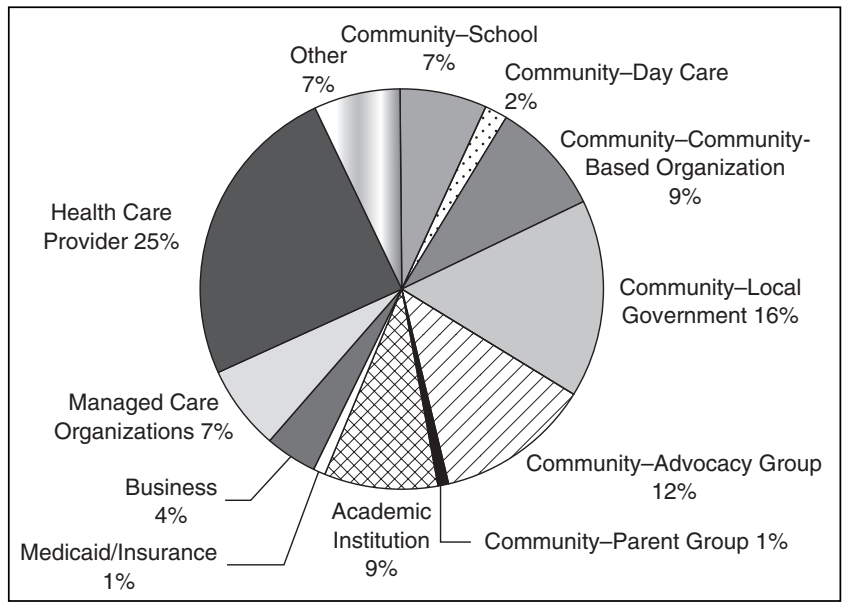

FIGURE 1 Organizational Membership of Allies Against Asthma Coalitions 2002-2004

need for something, then we moved in that direction." For example, the Finance Committee became the Sustainability Committee as the Institutionalization Stage began in Year 3.

\section{Membership}

The core members of a coalition are the key to its initial success. Previous experience with the health issue or experience with coalitions increases the commitment of these core members, although they may participate with varying levels of intensity (Brager, Sprecht, \& Torczyner, 1987). The core group must recruit community stakeholders, those committed to the issue, and a broad constituency of organizations that vary according to expertise, sectors, perspectives, and backgrounds (Butterfoss \& Kegler, 2002).

The size of the Allies coalitions varies from 40 to 76 members $(M=57)$. Nearly $76 \%$ of members represent an organization, $11 \%$ represent themselves as individuals, and $17 \%$ represent themselves and an organization. All Allies coalitions have diverse organizational partners. The types of organizations and mean percentage of partners representing the community and other sectors are shown in Figure 1. According to the definition of community defined through a participatory process and discussed in Peterson et al. (2006 [this issue]), approximately $47 \%$ of member organizations are designated as community representatives and include schools; day care; local government, including health departments; advocacy groups; parent groups; and community-based organizations (CBOs), such as neighborhood councils, ethnic and minority groups, religious or faith-based organizations, youth and/or women's organizations, and other coalitions. Health care providers make up the next largest group (25\%).

Recruitment of new members was enhanced by (a) conducting gap analyses to identify needed partners, (b) existing community relationships, (c) lead agency reputation, (d) being inclusive and diverse, and (e) providing convenient meeting times, locations, parking, child care, and translation services. Recruitment methods included using existing personal and professional networks, word of mouth, flyers posted in community locations, invitations (in person, mail, e-mail), and contacts with organizations that conducted asthma activities. Except for the ALIANZA, coalitions confirmed that parents and/or caregivers of children with asthma, ethnic and minority groups, and the media were not well represented and were most important to recruit. Most coalitions struggled to recruit and engage community residents and large institutions (e.g., insurers, large employers). The main strengths and challenges of membership in Allies coalitions are shown in Table 2. Some issues may be seen as strengths and challenges, such as diversity, and broad representation from many sectors and professional levels.

\section{Leadership and Staff}

Coalition leaders organize the structures through which coalitions accomplish their work, such as steering committees comprising work group leaders. Effective leadership requires a collection of qualities and skills that are found in a team of committed leaders. A consistent relationship is reported between leader competence and member satisfaction (Butterfoss \& Kegler, 2002), and both are related to member perceptions of leader competence (Glidewell, Kelly, Bagby \& Dickerson, 1998) and leader commitment to common goals (Braithwhite, Taylor, \& Austin, 2000; Kegler et al., 1998). In many coalitions, paid staff assume leadership functions such as setting agendas, facilitating meetings, encouraging membership involvement, and building community capacity (Sanchez, 2000). Staffing is related to intermediate indicators of coalition effectiveness that include member-related outcomes (e.g., satisfaction and participation), plan quality, resource mobilization, and implementation of activities (Butterfoss, Goodman, \& Wandersman, 1996; Kegler et al., 1998; Rogers et al., 1993).

Staff for the Allies coalitions includes directors or project investigators, evaluators, project managers and administrators, nurses, health educators, community health workers, administrative support staff, and other consultants. Some coalitions collaborate with other 
TABLE 2

Strengths and Challenges of Allies' Members

Strengths of Membership

Diversity of member skills and/or talents

Asthma recognized as important issue

Broad representation from many sectors

Highly motivated and committed individuals

Collaboration and lack of interorganizational conflict

High level of individual expertise

Core of strong leaders
Challenges of Membership

Achieving ethnic and racial diversity

Obtaining support and participation of specific groups (e.g., families of children with asthma, grassroots organizations, and managed care organizations)

Balancing needs of professionals and grassroots groups and/or members

Maintaining members' involvement and interest, especially during planning

Managing conflict because of diverse interests, values, and approaches

Sustaining participation over a large geographic area, while implementing activities in prioritized communities

Recruiting leaders organizations to provide contractual services for evaluation, clinical, and outreach services. Although coalition staff fluctuated throughout the 4-year grant period, each site employed an average of six full-time staff persons (or their equivalent) to manage the coalition, conduct its activities, and coordinate its evaluation. Naturally, this infrastructure is expected to change as coalitions transform themselves during maintenance and institutionalization. In the Allies coalitions, leadership is a joint responsibility of the steering committee staff and report challenges such as (a) managing staff turnover, (b) finding community-based staff with technical expertise, (c) finding qualified volunteer leaders with coalition experience, (d) providing adequate training (e.g., research methods), and (e) depending on volunteers for leadership while demanding accountability.

According to CSAS, nearly $95 \%$ of members reported that the coalitions are well managed, and 96\% report that the staff supports the coalitions' work. More than $90 \%$ of respondents reported that members take responsibility for getting the work done, which is supported by the fact that $32 \%$ serve as coalition leaders. About $84 \%$ of respondents were clear about the roles of staff as compared to members. Overall, members were satisfied with leadership and agreed that leaders were respected by the community and by the coalition (98\%). Most agreed that leaders built consensus, worked collaboratively with members, and sought others' views; however, many felt that leaders controlled discussions $(56 \%)$ or decisions $(65 \%)$.

\section{Coalition Processes}

Coalitions engage in basic functions such as communicating, making decisions, and managing conflict to reach goals (Butterfoss \& Kegler, 2002). Frequent, productive communication among members increases satisfaction, commitment, and implementation of strategies (Kegler et al., 1998; Kumpher, Turner, Hopkins, \& Librett, 1993; Putnam, 1993; Rogers et al., 1993). Likewise, member influence in decision making is related to increased satisfaction and participation (Butterfoss et al., 1996; Mayer et al., 1998). Although conflict is intrinsic to coalitions (Kegler et al., 1998; Mizrahi \& Rosenthal, 1992), its resolution strengthens the coalition, increases capacity, and leads to goal attainment (Mayer et al., 1998).

Communications. Allies coalitions use many communication methods to share meeting announcements, events, minutes, journal and newspaper articles, and other business. Most rely on e-mail, phone, fax, and face-to-face contact (in and outside staff, coalition, and committee meetings). Three coalitions produce quarterly or monthly electronic newsletters, and four have Web sites; four have committees to increase communication between the community and other projects such as providing translation services as needed. FAM Allies uses nominal group process to enhance communication, and the ALIANZA has a facilitator with community development expertise. 
According to CSAS, Allies members rated communication between coalition staff and/or leadership and its members as effective $(88 \%)$ and meeting notification as efficient (92\%). Members agreed that they communicate well among themselves (95\%) and that staff facilitates the process (90\%). Members agreed that they could talk openly and honestly at meetings (92\%) and respect each others' point of view even if they disagree (95\%). Communication challenges reported in key informant interviews were presenting difficult clinical or evaluation concepts to lay members and dealing with geographic barriers. One coalition found that open dialogue actually provides more chances for disagreement.

Decision making. Nearly $96 \%$ of Allies members were comfortable with the decision-making process. Members reported that coalitions made decisions using a consensus method (62\%) and/or by having the steering committee make decisions $(28 \%)$. Other methods were voting by members $(21 \%)$ or having the lead agency $(6 \%)$ or coalition chair $(6 \%)$ decide. Coalition chairs $(82 \%)$, work group chairs $(75 \%)$, or staff $(64 \%)$ were viewed as having a lot of influence in making decisions about activities and policies. Fewer felt that members as a group (38\%) or individual members $(19 \%)$ had a lot of influence.

Conflict resolution. When asked about the conflict that occurred in their coalition, Allies members reported less $(49 \%)$ or about the same (45\%) amount of conflict as expected. Members rated the following as causing the most conflict: differences in opinion about coalition mission (45\%), specific objectives (64\%), best strategies to achieve a goal $(76 \%)$, which gets public exposure and recognition (30\%), and procedures for completing the work ( $45 \%)$. The main strategy used to address conflicts was open debate about opposing viewpoints $(57 \%)$.

Planning and assessment. A coalition usually engages in an extensive assessment and planning process that makes successful implementation of strategies more likely. Quality plans contribute to successful implementation (Butterfoss et al., 1996; Kegler et al., 1998; Kumpfer et al., 1993), even though many coalitions fail to produce those (Kreuter, Lezin, \& Young, 2000).

During planning, Allies coalitions used many needs assessment methods. All coalitions reviewed extant data and held planning meetings, three used assetmapping exercises, three held member retreats, six conducted focus groups, four conducted key informant interviews, two used nominal group process, and two conducted surveys. During interviews, coalitions viewed planning periods as "intense and collaborative" with "everyone being heard." Some described significant tension and conflict as partnerships and relationships were being defined or redefined. The planning process was regarded as "indispensable" for defining the asthma problem, identifying partners, balancing the needs of research with community advocacy, and engaging partners in the work. During the planning period, coalitions completed needs assessments, identified and prioritized activities, and developed a community action plan (CAP) that served as a blueprint for implementation. They continued to build their coalitions, and refine data on asthma, community resources, and promising practices. New coalitions spent more time building relationships and coalition structures, and all faced the challenge of planning new activities while implementing or maintaining others.

I think it's a really important point when you are talking about coalition development that, even though it was a planning time, the ability to involve the whole coalition in every part of the process, keep them informed, get feedback and actively think about some of the pieces of the project, I think, was very important and successful.

Coalition member, Philadelphia Allies Against Asthma

\section{DISCUSSION AND IMPLICATIONS FOR PRACTICE}

Allies coalitions obviously had different histories, cultural and geographic origins, lead agencies, and years of experience in working together. Only one had no previous experience with community partnerships. In truth, all either were created or transformed themselves to respond to the request for funding. The RWJF funding then may have been the strongest contextual factor that affected coalition formation. Most Allies coalitions shifted their missions or expanded their issues to be eligible for funding. The literature abounds with examples of coalitions that "morph" or recycle themselves in search of new funding opportunities. This funding helped provide the impetus for community partners in the seven sites to contribute their financial and in-kind resources to the collaborative 
effort. This very strength can, however, become a liability when funding ends and partners do not have the resources and/or the commitment to continue coalition interventions.

Because two of the three newest coalitions took the longest to form, we are reminded of the distinct disadvantage that lack of experience brings. Precious time must be spent to recruit members, create coalition structures, and develop equitable and efficient governance processes. The experienced coalitions could shortcut this process and implement strategies more rapidly. However, ethical considerations are often more crucial than efficiency. In localities with significant health disparities, building new coalitions is warranted, even if more time and technical assistance are required to do so.

The most notable similarities among coalitions are related to structures, leadership, staffing, and relationships. Allies coalitions are modest in size, and nearly three fourths of members represent organizations rather than individuals. Although diverse, the desire to increase coalition representation of parents and caregivers of children with asthma, minority groups, managed care organizations, and the media was expressed by nearly all coalitions.

Although Allies coalitions were not mandated to create the same structures, organizational charts show that they are quite similar. All have steering committees, committees, elected leadership, regularly scheduled meetings with agenda, and missions. Perhaps the training and educational experiences provided by the National Program Office and the National Advisory Committee through annual grantee meetings, weekly newsletters, and teleconferences made uniformity more likely. These entities influenced the formation, and perhaps even the effectiveness, of these coalitions by sharing their wisdom and experience and providing focused support and educational and/or evaluation resources to the sites. Similarly, the informal network that developed among project directors and program managers encouraged sharing of products, ideas, and experiences. Similarities in structure may also be because of prior experiences working in coalition settings. Most coalitions changed their initial structure by disbanding, combining, or developing new committees to be responsive to changing priorities and work plans. All Allies' coalitions reached coalition process objectives during formation to include hiring and recruitment, creation of useful coalition structures and products, and development of a participatory, committed group of members and leaders.

Staff and volunteer leadership represent a considerable expenditure of human resources. Thus a strong coalition infrastructure is needed to move each coalition from the drawing board to the tasks involved in directing this collaborative initiative. Coalition members rated their staff and leaders highly in all areas of coalition management and in collaborative skills. They agreed that leaders intentionally sought others' views; used the skills and talents of others; created an appropriate balance of responsibility between leader, staff, and members; and skillfully resolved conflict.

Although Allies coalitions have different staff roles and responsibilities, one similarity has been the need for visionary and operational skills. Working closely with coalition members, visionary leadership is often provided by the principal investigator and/or project director. These individuals, who include physicians and public health professionals and researchers, bring their knowledge, experience, and contacts to help facilitate and shape the coalitions' vision and role in the broader community. Coalitions have identified the need for staff to provide operational oversight. By the time coalitions began to implement programs in the 2nd year, six of seven had hired full-time coordinators-most often a master's prepared public health professional-to oversee implementation of the CAP and/or coalition development. Some coalitions also contracted for additional staff support, especially in the area of evaluation.

\section{Limitations and Suggestions for Future Research and Practice}

The data in this article are self-reported, and bias is inevitable. Survey data was averaged throughout the project period, and further analysis may show that respondents' views changed over time in subtle, but critical, ways. Data were collected at different times, and results may be affected by unique time-sensitive events. For example, the ratings of coalition characteristics in the CEI were overly positive. This tool was initially developed to help coalitions assess their progress and not to compare differences among coalitions (Butterfoss, 2004). Perhaps using an outside evaluator or refining the CEI would reduce bias and discriminate differences among coalitions to provide more variation for future studies. In fact, comparing the Allies coalitions with other multisite asthma projects (e.g., Centers for Disease Control's [CDC] Controlling Asthma in America's Cities and California Endowment's California Action to Fight Asthma) would be worthwhile, from research and practice aspects.

Our results are based on preliminary data analyses and written prior to accomplishment of long-term objectives and while Allies coalitions continue to operate. 
How effective these coalitions will be in ultimately reducing hospitalization rates and emergency department visits and improving the quality of life for children with asthma and their families is unknown. These initial findings, however, may be useful to other coalitions who are struggling with issues surrounding successful mobilization and formation.

\section{CONCLUSION}

Allies communities showed remarkable similarities in their ability to form viable coalitions as long as time was not a consideration. However, their varying ability to progress beyond formation may be attributed to their level of maturity and experience in partnering with other organizations (see Butterfoss et al., 2006). A community's readiness for collaboration and its experience with coalitions must be considered before funding. The question is not whether a community can develop a coalition, but rather the length of time, challenges faced, and support and resources needed to make the coalition effective in reaching its goals.

\section{REFERENCES}

Brager, G. A., Sprecht, H., \& Torczyner, J. L. (1987). Community organizing (2nd ed.). New York: Columbia University Press.

Braithwaite, R., Taylor, S., \& Austin, J. (2000). Building health coalitions in the Black community. Thousand Oaks, CA: Sage.

Butterfoss, F., Goodman, R., \& Wandersman, A. (1993). Community coalitions for prevention and health promotion. Health Education Research, 8(3), 315-330.

Butterfoss, F., Goodman, R., \& Wandersman, A. (1996). Community coalitions for prevention and health promotion: Factors predicting satisfaction, participation and planning. Health Education Quarterly, 23(1), 65-79.

Butterfoss, F. D. (2004). Building effective coalitions with consultation and technical assistance: Virginia's Healthy Start initiative, Health Promotion Practice, 5(2), 118-126.

Butterfoss, F. D., Gilmore, L. A., Krieger, J. W., Lachance, L. L., Lara, M., Meurer, J. R., et al. (2006). From formation to action: How Allies Against Asthma coalitions are getting the job done. Health Promotion Practice, 7(Suppl. 2), 34S-43S.

Butterfoss, F. D., \& Kegler, M. C. (2002). Toward a comprehensive understanding of community coalitions: Moving from practice to theory. In R. DiClemente, L. Crosby, \& M. C. Kegler (Eds.), Emerging theories in health promotion practice and research (pp. 157-193). San Francisco: Jossey-Bass.

Clark, N., Baker, E., \& Chawla, A. (1993). Sustaining collaborative problem-solving: Strategies from a study in six Asian countries. Health Education Research, 8(3), 385-402.

Clark, N. M., Doctor, L. J., Friedman, A. R., Lachance, L. L., Houle, C. R., Geng, X., et al. (2006). Community coalitions to control chronic disease: Allies Against Asthma as a model and case study. Health Promotion Practice, 7(Suppl. 2), 14S-22S.
Dill, A. (1994). Institutional environments and organizational responses to AIDS. Journal of Health and Social Behavior, 35, 349-369.

Fawcett, S., Paine, A., Francisco, V., \& Vliet, M. (1993). Promotion health through community development. In D. Glenwick \& L. A. Jason (Eds.), Promoting health and mental health in children, youth and families (pp. 233-255). New York: Springer.

Florin, P., Mitchell, R., \& Stevenson, J. (1993). Identifying training and technical assistance needs in community coalitions: A developmental approach. Health Education Research, 8(3), 417-432.

Glidewell, J., Kelly, J., Bagby, M., \& Dickerson, A. (1998). Community leadership: Theory and practice. In R. S. Tindale, J. Edwards, F. J. Posavic, F. B. Bryant, L. Heath, E. Henderson-King, et al. (Eds.), Applications of theory and research on groups to social issues (pp. 61-86). New York: Plenum.

Goldstein, S. (1997). Community coalitions: A self-assessment tool. American Journal of Health Promotion, 11, 430-435.

Goodman, R. M., \& Steckler, A. (1989). A model for institutionalization of health promotion programs. Family and Community Health, 11, 63-78.

Gray, B. (1989). Collaboration: Finding common ground for multiparty problems. San Francisco: Jossey-Bass.

Kegler, M., Steckler, A., McLeroy, K., \& Malek, S. (1998). Factors that contribute to effective community health promotion coalitions: A study of 10 Project ASSIST coalitions in North Carolina. Health Education \& Behavior, 25(3), 338-353.

Kenney, E., \& Sofaer, S. (2000). The Coalition Self Assessment Survey: A manual for users. New York: City University of New York, Baruch College, School of Public Affairs.

Kreuter, M. W., Lezin, N. A., \& Young, L. A. (2000). Evaluating community-based collaborative mechanisms: implications for practitioners. Health Promotion Practice, 1, 49-63.

Kumpher, K., Turner, C., Hopkins, R., \& Librett, J. (1993). Leadership and team effectiveness in community coalitions for the prevention of alcohol and other drug abuse. Health Education Research, 8(3), 359-374.

Lachance, L. L., Houle, C. R., Cassidy, E. F., Bourcier, E., Cohn, J. H., Orians, C. E., et al. (2006). Collaborative design and implementation of a multisite community coalition evaluation. Health Promotion and Practice, 7(Suppl. 2), 44S-55S.

Lasker, R., Weiss, E., \& Miller, R. (2000, April 29-May 2). Promoting collaborations that improve health. Paper commissioned for the 4th Annual Community-Campus Partnerships for Health Conference, Arlington, VA.

Mayer, J., Soweid, R., Dabney, S., Brownson, C., Goodman, R., \& Brownson R. (1998). Practices of successful community coalitions: A multiple case study. American Journal of Health Behavior, 22(5), 368-377.

McLeroy, K., Kegler, M., Steckler, A., Burdine, J., \& Wisotzky, M. (1994). Community coalitions for health promotion: Summary and further reflections [Editorial]. Health Education Research, 9(1), 1-11.

Mizrahi, T., \& Rosenthal, B. (1992). Managing dynamic tensions in social change coalitions. In T. Mizrahi \& J. Morrison (Eds.), Community organization and social administration (pp. 11-35). New York: Haworth. 
National Network for Collaboration. (1996). Collaboration framework . . . addressing community capacity. Fargo, ND: Author.

Nelson, G. (1994). The development of a mental health coalition: A case study. American Journal of Community Psychology, 22(2), 229-255.

Peterson, J. W., Lachance, L. L., Butterfoss, F. D., Houle, C. R., Nicholas, E. A., Gilmore, L., et al. (2006). Engaging the community in coalition efforts to address childhood asthma. Health Promotion Practice, 7(Suppl. 2), 56S-65S.

Putnam, R. (1993). Making democracy work. Princeton, NJ: Princeton University Press.

Reininger, B., Dinh-Zarr, T., Sinicrope, P., \& Martin, D. (1999). Dimensions of participation and leadership: Implications for community-based health promotion for youth. Family and Community Health, 22(2), 72-82.

Rogers, T., Howard-Pitney, B., Feighery, E., Altman, D., Endres, J., \& Roeseler, A. (1993). Characteristics and participant perceptions of tobacco control coalitions in California. Health Education Research, 8(3), 345-357.

Sanchez, V. (2000). Reflections on community coalition staff: Research directions from practice. Health Promotion Practice, 1(4), 320-322.

Wolff, T. (2001). Community coalition building-Contemporary practice and research. American Journal of Community Psychology, 29(2), 173-191. 